\title{
Suomalaisen valtio-opin perustajien sukupolvesta
}

\section{KARI PAAKKUNAINEN}

Suomen ensimmäisen valtio-opin professuurin perustamiseen (Helsingin yliopisto, 1921) ja nimittämiseen vaikuttivat monet seikat. Lähinnä halu kasvattaa itsenäisen Suomen "uusi sivistyneistö" ja erilaiset manner-eurooppalaiset akateemiset traditiot loivat näiden intrigien ehdot. Tässä artikkelissa myöhemmin tarkemmin esiteltävien Karl Robert Brotheruksen (1880-1949), Yrjö Ruudun (ennen vuotta 1927 Ruuth, 1887-1956) ja Rafael Erichin (1879-1946) ohjelmapuheenvuorot valtio-opin luonteesta sijoittuvat tiukahkoon akateemiseen tieteenalapohdiskeluun. Mutta heidän reaalihistoriallinen kokemuspiirinsä ja tulkintansa 1900-luvun alkupuolen valtiollisissa kriiseissä osoittavat hyvin näiden ei-akateemisten tekijöiden vaikutuksen valtioopin muotoon ja sisältöön.

Valtio-oppihan oli ennen institutionalisoimistaan käsite, jolla saatettiin kuvata tiettyjä historian aspekteja, normatiivisten tieteiden eräänlainen rajankäyntiväline tai apukeino yhteiskunnasta päin rakentavalle sosiologialle. Esimerkiksi Ruutu kiittikin väitöskirjassaan praktillisen filosofian ja valtioteorian tuntija Zackharias Castrénia siviilirohkeudesta tämän tuettua Ruudun työtä, "vaikka sen aihe on valittu yliopiston tähänastisen varsinaisen ainejärjestelmän ulkopuolelta" (Ruuth 1922a, esipuhe). Erichin (1924), Brotheruksen (1924) ja Ruudun (Ruuth 1922b) teoreettiset ideaalit voidaan löytää Manner-Euroopan teoreettisista metropoleista, lähinnä vuosisadan alun Saksasta. Kiinnostavin perustein ja äänenpainoin ne myös viestivät tämän sukupolven ja suomalaisen valtio-opin esitieteenaloista ja tulevista naapuritieteistä - oikeustieteestä, historiasta ja sosiologiasta.

Kysymys vallasta ja monissa suhteissa myös politiikka olivat suhteellisen pitkään esittäytyneet yliopistoestradeilla - saatettiinhan maan valtionyliopistoa pitää 1800-luvulla ja miksei vielä jääkäriliikkeenkin aikoihin maan poliittisen toiminnan keskuksena. Myös tieteenalojen konstituutiopuheenvuoroissa oli suoraan puututtu valtio- ja politiikkakäsitteisiin - niitä identifioiden. Vahvan oikeustieteen piirissä - joka toimi Rafael Erichin debattitaustana - olivat keskeisiä nimiä lähinnä Leo Mechelin ja Robert Hermansson. Edellinen torjui aiemmin tärkeän valtiofilosofisen pohdiskelun juridiikan kannalta hyödyttömänä ja sitoi valtion käsitteen lähinnä reaaliseen oikeuskäytäntöön, vapausrajoihin ja kulttuuriin (Mechelin 1912). "Politiikka" voitiin mieltää toisaalta normatiivisena tieteenä ja toisaalta eräänlaisena valtiotaitona (ks. tarkemmin Palonen 1980, 84-90). Myös Hermansson inspiroitui saksalaisesta Allgemeine Staatslehre -tradition varhaisesta valtio- ja oikeuspolemiikista, erityisesti niin kutsutusta Verberin-Labandin koulukunnan työstä. Häntä voidaankin pitää käsitelainopin maahantuojana. Koulukunnan mukaan valtio määrittyi oikeushenkilönä ja -subjektina, jolla oli valtio-oikeudelliset velvollisuudet ja oikeudet. Valtiovalta muodostui näin oikeuskäsitteen sisäiseksi kokonaisuudeksi. (Erit. Klami 1977a, 122-131.)

Filosofisempaa valtio-opin määrittelymahdollisuutta edusti taasen esteetikko K. S. Laurila - K. R. Brotheruksen kilpahakija vuoden 1922 valtio-opin virantäytössä. Hän määritteli "yleisen valtio-opin ... valtion, sen olemuksen, rakenteen ja elämän perusilmiöitten ymmärtämiseen ja 
selvittämiseen" tähtäävänä tieteellisenä toimintana. Valtion tarkoituksia ei voinut tutkia, jollei käsitetty valtion olemusta. (Laurila 1923, vrt. Palonen 1980.)

Brotheruksen "edustamassa" historiatieteessä oli suomalaisten keskustelu kehittynyt individualistisen historiankirjoituksen kritiikin kautta maan poliittista historiaa lähellä oleviin 1910-luvun teemoihin. Yrjö Koskisen, Th. Reinin, J. R. Danielssonin ja August Hjeltin välityksellä kehkeytyi "Verein für Sozialpolitik" -perinne Suomessakin. Myös kansantaloustieteilijöiden piirissä vaikuttaneessa perinteessä epähistoriallisuus ja individualismi nousivat yhteiskunnallisten tieteiden puitteissa kritiikin kohteiksi. Toisaalta kehitettiin modernimman patrioottisuuden muotoja ja huolehdittiin sosiaalisista ongelmista, jotka olivat vaarantaneet valtiollisen yhtenäisyyden takaamista. Myös katederisosialismista inspiroitunut J. R. Danielsson pyrki yhdistämään tieteellisen ajattelun myös päivänkohtaisiin ongelmiin ja ennakoimaan lähitulevaisuuden kehitystä. Menneisyys hahmottui alati "kehittyvänä prosessina", jossa kansallisuusaate toteutui ja valtiokokonaisuus muodostui. Saksalaisen Gustav Schmollerin jälkeen entistä kokonaisvaltaisemman historiakäsityksen muodostamisen esikuvaksi nousi Suomen periferiassa Karl Lambrecht. Hänen kollektiivisten metodiensa ympärillä käytyyn "Methodenstreitiin" osallistui myös K. R. Brotherus yhtenä uusien ajatusten innokkaimmista kannattajista. Lambrechtilaisuus ei merkinnyt Suomessa yhteiskuntateoriaa tiukassa tieteellisessä mielessä. Siitä muodostui kulttuurihistoriallinen tutkimusote, jossa myös poliittiset tekijät saivat huomiota. Tämän uuden suunnan ytimen muodostivat myöhemmin Gunnar Suolahti ja Väinö Voionmaa. Samalla kansallinen poliittinen kokonaisuus alkoi vallata alaa tutkimuskohteena - olihan sen legitiimisyydestä jouduttu ennen maan itsenäistymistä taistelemaan. (Erit. Ahtiainen 1983.)

Sosiaalinen ja poliittinen näkökulma ei ollut mukana vain historiassa. Lähinnä "westermarckilaisessa" tieteellisessä viiteryhmässä olivat valtiomuodostuksen yleisemmät sosiaaliset teoriat ja käsitteet näkyvästi esillä. Tällainen naturalistinen ja valtiososiologistinen ote esittäytyi esimerkiksi Rudolf Holstin väitöskirjassa sodan suhteesta valtion syntyperään (1913). Toisaalta Rafael Karsten - joka propagoi yliopiston hallinnossakin yleistä valtio-oppia "sosiologis-filosofisena" oppiaineena - tarjosi Ruudunkin ihailemia sosiologisen valtioteorian auktoriteetteja Gumplowiczia ja Ratzenhoferia (1893) valtio-opin tutkintovaatimuksiin. (Ks. esim. Palonen 1983.)

Erilaisista tieteentraditioistaan huolimatta Erich, Brotherus ja Ruutu kuitenkin löysivät yhteisiä keskusteluauktoriteetteja - lähinnä Allgemeine Staatslehre -traditiosta, erityisesti Georg Jellinekistä (1920). Suhde Jellinekiin ei kuitenkaan luo yhtenäistä perustaa tieteenalakäsityksille - varsinkaan Ruudun osalta. Suomalaisen valtio-opin perustajasukupolven käsitykset varioivatkin kiinnostavasti niin valtion, politiikan kuin valtiotaidonkin käsitteiden osalta. Omassa yhteiskunnallisessa osallistumisessaan ja opetuskäytännössään jokainen heistä kuitenkin osoitti omalla tavallaan, kuinka valtioteorioilla ja poliittisella sivistyksellä oli vaikutuksensa poliittiseen kulttuuriin. Laaja-alaista valtioteoreettista keskusteluasetelmaa oli omiaan ylläpitämään dramaattiset valtiolliset tapahtumat vuosisadan alussa - valtion, itsenäisyyden ja oikeuden käsitteet olivat myös jotain täysin omakohtaisesti koettua. Kriisit tuli läpikäydä myös käsitteellisesti. Ehkä juuri tämä, sinällään yksinkertainen empiristinen tosiasia, vaikutti myös siihen, että näiden kolmen tässä käsitellyn intellektuellin kunnioitus valtioteoriaa ja käsitettä kohtaan aina säilyi ja he torjuivat eri muodoin yksinkertaisen, abstraktin ja tutkimuskohteiltaan sektoroidun skientismin. 


\section{K. R. BROTHERUS - YLEISEN VALTIO-OPIN ENSIMMÄINEN PROFESSORI}

K. R. Brotherus valittiin Suomen valtio-opin ensimmäiseksi professoriksi vuonna 1924. Tarkkaan ottaen tämä ei pidä paikkaansa - jo 1600-luvulla Turun Akatemiassa oli historian ja politiikan professuuri, jota hoiti Michael Olai Wexionius (Nurmi 1983). Myös Åbo Akademiin oli 1920-1 uvun alussa perustettu "yleisen valtio-opin ja politiikan" professuuri, mutta siihen valittu nuori ja lahjakas dosentti Gunnar Rexius kuoli yllättäen ja toimen täyttö siirtyi aina vuoteen 1942 saakka (Anckar 1976, 21-23).

Vaikka K. R. Brotheruksen tiedekäsitys muuttuikin ja sai täsmällisen muotonsa vasta virantäyttöprosessissa, ei hänen tutkijankuvastaan voitane unohtaa hänen historiantieteilijän taustaansa. Jo nuorena maisterina Brotherus oli hyvin herätteellisin ja populaarein tavoin osoittautunut saksalaisen lambrechtilaisen kollektiivisen historiantutkimusmenetelmän "innokkaaksi aseenkantajaksi”. Suomalaista historiantutkimusta hän piti kauttaaltaan individualistisena ja yksityiskohtiin takertuneena. Aivan täysin Brotherus ei kuitenkaan samastunut Karl Lambrechtin yhteiskuntakokonaisuutta korostaviin metodisiin luonnehdintoihin ja kritisoi häntä yksilöä väheksyvistä katsomuksista. Yhteiskunnan ja yhteiskuntakokonaisuuden tai valtion välinen jännite sekä teoreettinen yksilön puolustaminen säilyivät jatkossakin keskeisinä pohdintaulottuvuutena Brotheruksella. Oleellinen piirre Brotheruksen tiedekonseptiossa vuosisadan alussa oli myös se, että hän pitäytyi sekä Rankin että klassisissa kysymyksissä "wie es eigentlich gewesen ist" ja "wie es eigentlich geworden ist" rinnakkaisina tutkimusta ohjaavina näkökulmina. (Brotherus 1903, 3-10, 137; ks myös Ahtiainen 1982.)

Eräänlainen metodikeskustelu leimasi myös hänen väitöskirjaansa "Immanuel Kants Philosophie der Geschicte" (1905). Saksalaisessa tiedekeskustelussa argumentoiva Brotheruksen ote ei kuitenkaan merkinnyt yksioikoista kantilaisten tai uuskantilaisten oppien omaksumista. Brotheruksen valtio-opillistuminen tapahtui myöhemmin. Ehkä tämä "politisoituminen" osaksi liittyi hänen melko vahvoihin poliittisiin aktioihinsa.

Hän osallistui nuorsuomalaisena kamppailuun vahvan hallitusvallan ja monarkian puolesta. Samoin hän lukeutui kokoomuspuolueen perustajaintellektuelleihin. 1930- ja 1940-lukujen Brotheruksen - joka toimi pitkään Helsingin yliopiston rehtorina - maailmankuvaa ei yksinkertaisesti voi luokittaa kokoomuslaiseksi vaan hänen kommenteissaan esiintyi vanhaliberaaleja äänenpainoja, joissa sekä yksilön että kypsän ja demokraattisen valtiovallan puolustamisella oli osansa. Tämä merkitsi osin asenteellistakin "metafyysisten oppijärjestelmien" kritiikkiä ja tukeutumista anglo-amerikkalaiseen poliittiseen perintöön sekä aikakauden äärioikeiston toimien kritiikkiä. (Ks. esim. Brotherus 1940a ja "Rehtorin puheet lukukausien avajaisissa vuosina 1923-37".)

Virkaanastujaisluennosta "Valtio-opin suhde muihin tieteisiin" (1924a) muodostuikin ehkä merkittävin Brotheruksen valtio-opillisista linjapuheenvuoroista. Siinä hänen käsitejärjestelmänsä lähestyy Allgemeine Staatslehre -tradition keskusteluasetelmia - arvostaahan Brotherus artikkelissaan juuri Jellinekiä valtio-opin "kenties etevimpänä" teoreetikkona. Tätä tendenssiä ei tule kuitenkaan liioitella, sillä esimerkiksi Brotheruksen tapa esittää poliittisen historian ja valtio-opin suhde poikkeaa huomattavasti Jellinekistä. Tiettyä kokonaisnäkökulmaa tavoitteleva historiatiede suuntautui osaltaan samoihin tutkimuskohteisiin kuin valtio-oppikin. Eri tavoin tutkimusprosessissa esittäytyvät tarkasteluaspektit ja poliittisen historian keskittyminen 
"muuttuvaisuuden ja kehityksen tasoon" valtio-opillisen "olemuksellisen ja pysyväisen" tutkimuskohteen sijasta kuuluivat edelleen Brotheruksen määrittelyyn. Nämä mielipiteet eivät kuitenkaan merkinneet, että Brotherus olisi torjunut historiatieteen mahdollisuudet selittävään otteeseen. Brotheruksen erottelua onkin verrattu Herman Hellerin myöhemmin tekemään jakoon historia- ja rakennetieteiden välillä. Samalla Brotherus kuitenkin halusi säilyttää uskonsa yhteiskunnallisen ja valtiollisen elämän tiettyyn yleiseen historiallisuuteen ja välttää tieteenaloihin sisältyvää doktrinalismia. Hän myös osoitti omissa töissään, miten "pysyväisyys" ja "muuttuvaisuus" tarvitsivat toisiaan. Toinen asia on, pystyikö Brotherus oppialan "suomalaisena johtajana" välttämään doktrinaarista tieteenalan vartijaroolia - ainakin Ruutu koki, ettei Brotherus ymmärtänyt sosiologisenergeettistä valtioteoriaa ja toimi "fakkitieteilijän" tavoin. (Brotherus 1924; 1927, Palonen 1980, 92-100; Paakkunainen 1985.)

Hyvin määrätietoisesti Brotherus käsitteellisti erilleen valtio-oikeudellisen normatiivisuuden ja "tosiasiallisia ilmiöitä" tutkivat valtiotieteet. Jako ei silti merkinnyt näiden alueiden tieteellisen vuorovaikutuksen relevanssin kieltämistä. Tällä dualismilla oli kuitenkin yhteytensä Jellinekin normimaailman ja "sosiologisen" todellisuuden vahvaan kahtiajakoon, teorian tiettyyn januskasvoisuuteen (Brotherus 1924a; vrt. Jellinek 1920, 10-19, 84-99). Brotherus halusi torjua myös luonnonlaki-analogiat valtio-opin piiristä. Uuskantilaisen saksalaiskeskustelun peruja olivat myös Brotheruksen tavat arvostella geopoliittisen koulukunnan oppeja. (Brotherus 1924a.)

Tutkimuskäytännössä Brotheruksen kiinnostuksen kohteiksi nousivat historiallis-metodologisten pohdiskelujen lisäksi lähinnä valtiollisten laitosten, parlamentarismin ja poliittisen kulttuurin tutkimus - muutamia teoreettis-filosofisia metodi- ja klassikkopuheenvuoroja unohtamatta (ks. erit. Brotherus 1940b; 1940c; 1944; 1946; 1947). Huomattavaa on myös tässä yhteydessä se, että Brotheruksen opetussisällöt eivät radikaalisti poikenneet Yrjö Ruudun harrastamista aihepiireistä, huolimatta heidän välisistään vahvoista tieteellisistä ristiriidoista ja intrigeistä (Paakkunainen 1985).

Valtiotieteiden yleisen tehtävän hän katsoi liittyvän "valtion toiminnan ja olemuksen valaisemiseen". Ne lukeutuivat laajempaan yhteiskuntatieteiden ryhmään, missä ne valottivat "vain yhtä puolta yhteiskuntaelämässä”. Samoin hän jakoi - joskin jälleen hyvin väljärajaisesti - valtiotieteiden tutkimusperiaatteet "teoreettisiin, deskriptiivisiin ja soveltaviin" suuntauksiin. Valtiotieteiden joukossa hyvin keskeiseen asemaan nousseella valtio-opilla oli tehtävänään "tutkia valtiota yleiseltä" ja juuri "pysyväisten ilmiöiden" kannalta katsoen. Erityinen rajaus oli myös se, että Brotherus liitti valtio-opin keskeisimmät ongelmat valtion tarkoituksiin, esimerkiksi sen "yleisiin sisällöllisiin tarkoitusperiin". Erityinen valtio-oppi ("besondere Staatslehre") taasen rajautui Brotheruksen mukaan tutkimuskohteiltaan erityisiin, määrättyihin valtiolaitoksiin. Tässä yhteydessä Brotherus korosti vertailevan eli komparatiivisen valtio-opin mahdollisuuksia - lähinnä oli kyse valtiollisten laitosten rinnakkaisesta tarkastelusta. (Brotherus 1924a; erit. 1924b.)

Tieteen modernisoituminen merkitsi Brotherukselle lisäksi sitä, että oli luovuttava kaikista spekulatiivisista tutkimusmenettelyistä ja tutkimuksen tuli "silloinkin kun se pyrki yleistä laatua oleviin tuloksiin" perustua "induktiivisesti tehtyihin havaintoihin valtiosta ja valtiollisesta elämästä" sellaisena kuin se todellisuudessa on esiintynyt. Tämä kritiikki ei ollut ristiriidassa yleisen valtio-opin "teoreettisuuden ja systemaattisuuden" tai sen filosofisuuden ja käsitteellisen tason kehittämisen kanssa. Päinvastoin Brotherus uskoi valtio-opin laajempaankin, eräänlaiseen "kielenhuoltotehtävään". (Erit. Brotherus 1924b; 1940c; 1947.) 
Induktivistisiin ja empiristisiin kantoihin liittyi erityisesti 1940-luvulla myös muille aikalaisille - kuten Jussi Teljolle ja eräille muille Eino Kailan filosofiasta inspiroituneille - metafysiikan kritiikki ja sen yhdistäminen suhteellisen epämääräisiin ajatuksiin olemusmystiikasta. Tällaiset kirjoitukset limittyivät saksalaisen totalitarismin ja neuvostoliittolaisen "todellisen demokratian" arvosteluun. Brotherusta ei voi kuitenkaan pitää minään naiivina empiristinä. Hän vaali valtio-opin teoreettista luonnetta ja koki käsitteelliset abstraktiot välttämättöminä tieteellisen työn apuvälineinä. Näin Brotherus myös joissain suhteissa samastaa käsitteellisen ajattelun ja metafysiikan. (Erit. Brotherus 1940c; 1947.)

Valtio-opin muodostumisen kannalta on tärkeää tarkastella myös "politiikan" ja "valtion" käsitteitä Brotheruksen tiedekäsityksessä. Tapa määritellä yleinen valtio-oppi nimenomaan valtion tarkoitusten kautta jo tavallaan osoitti, että hän preferoi valtiokäsitettä. Tämä tapa ei ollut välttämättä yleinen - esimerkiksi Jellinekin "Allgemeine Staatslehressä" poliittisen käsite kattoi myös valtiollisen alueen. "Politiikka" kuului Brotheruksen ajattelussa sovellettujen valtiotieteiden joukkoon, jonka määrittely "ahtaassa mielessä" samastui "valtiotiedon oppiin". Mutta "tieteisopissa" käsite politiikka oli hyvin monisisältöinen. Valtiotaito sinällään ei ollut opittavissa, mutta valtiomiehet tarvitsivat "taitoa" siinä, missä esimerkiksi maalaustaiteilijat perspektiivi- ja värioppejaan. Toisaalta Brotherus oli kuitenkin tiukempi ja näki mahdollisuudet valtiotaidon opin tulkitsemiseen normatiivisena tieteenä eli "käytännössä sovellettaviin normeihin tähtäävänä tieteenä" hyvinkin kiistanalaisena:"... tieteellisen luonteensa se voi säilyttää vain, jos se ottaa selvittääkseen valtiotaitoa ja valtiollisia periaatteita sellaisina kuin nämä todellisuudessa ovat esiintyneet taikka esiintyvät”. Näin tulkittuna politiikkaa oli mahdollista lähestyä teoreettisesti, mutta itse käytännöllinen poliittinen aktiviteetti ei voinut muodostua tieteelliseksi. (Brotherus 1924c; vrt. Palonen 1980, 92-102.)

Valtiomiesten kykytekijänä "valtiotaito" oli kiinnittynyt Brotherukselle laajemminkin tyypilliseen puolue- ja intressipiirien erityispyrkimykset ylittävään "valtiolliseen tarkoituspohdiskeluun". Brotherus näki puolueet ja ideologisen ryhmityksen usein hyvin doktrinäärisenä. Samoin hän tarkasteli valtionäkökulmasta poliittisen kehityksen kypsyystekijöitä tai puolusti yksilötason poliittista tahdonmuodostusta. Valtio ei jää vain poliittisten voimien instrumentiksi, vaan se osaltaan kantaa yleistä etua. Näin valtio saa poliittisen subjektin ominaisuuksia, vaikka yleisemmällä tasolla poliittiset subjektit muodostuvatkin yksilöistä, kuten juuri valtion "valtiomiehistä". Tällaisen käsityksen aatteellista yhteyttä liberaaliseen oikeusvaltioajatteluun onkin syystä korostettu: "Eduskunnan" tuli "demokraattisessa maassa, ennen kaikkea osata hallita". Esimerkiksi yliopiston rehtorina hän halusikin nostaa poliittisen kulttuurin tasoa ja huolehtia siitä, ettei paluuta 1920-luvun vähemmistöparlamentarismiin ja järjestelmän kriisiaikoihin enää olisi. Tämä huoli poliittisen valtakulttuurin toimivuudesta ei jää yksipuolisen ohjelmalliseksi vaan hän edustaa liberaalia ideaalia, jonkinlaista tasapainoa demokraattisessa valtiossa konstituoidun yleisen edun ja yksilöiden luovuttamattomien oikeuksien välillä. Tällaisen dualismin individualistiset tekijät tulevat esiin esimerkiksi henkilöperustaisen edustuksellisuuden puolustamisessa itsetarkoituksellista puoluepolitiikkaa ja aatteellisuutta vastaan. Samalla Brotheruksen historiakäsitykselle oli laajemminkin ominaista ajatus hallitsijoiden ja hallittavien dualismista ja sen jatkuvuudesta. Tämä näkyi myös tieteellisten tarkastelujen vaikeuksissa välittää tai siirtyä politiikan yksilötasoisista subjekteista valtion tasolle. Paljaimmillaan tämä esittäytyi kyynisen realistisessa ajatuksessa, että vain ajoittaiset "vaalit auttoivat 
ihmisiä ylittämään pysyväisen roolinsa vallan objekteina”. (Brotherus 1924c; 1939; 1944; 1946; 1947; Palonen 1980, 92-98; Paakkunainen 1985.)

Suomalainen valtio-oppi ei suinkaan ponnistanut liikkeelle yhtenäisenä oppijärjestelmänä. Jo 1920-luvun puolivälissä tuore professori Brotherus hankkiutui tiukkaan arvovaltakiistaan tohtori Yrjö Ruudun kanssa tämän hakiessa valtio-opin dosentuuria. Ruudun valtioteorian juuret olivat energetiikassa, sosiologiassa ja 1800-lukulaisessa evoluutiouskoisessa rationalismissa. Brotherus ei uuskantilaisesti värittyneessä Allgemeine Staatslehre -traditiossaan kyennyt tai halunnut ymmärtää Ruudun sosiologisen kehitysobjektivismin sisältämää normatiivisuutta (ks. erit. Ruuth 1922a; 1924a; vrt. Palonen 1983, 115-120). Nämä keskeiset maan valtio-opin muotoilijat puhuivat systemaattisesti "toistensa ohi" ja uusivat kiistansa eri vaiheissa aina 1940-luvulle saakka. Heitä pidettiinkin suomalaisen valtio-opin "kissana ja koirana".

\section{YRJÖ RUUTU SOSIOLOGISEN VALTIO-OPIN PROPAGOIJANA}

Yrjö Ruudun ohjelmakirjoitus "Poliittinen tiede ja sen metodi" (1922b) voidaankin vallan hyvin lukea juuri Brotheruksen kirjoituksen rinnalla - jolloin heidän teoreettiset kontrastinsa tulevat hyvin esiin. Ruutu esitteli artikkelissaan samana vuonna ilmestyneeseen väitöskirjaansa sisältyneitä politiikka- ja valtiokäsitteitä (1922a). Ruudun valtio-oppia ei voi kuitenkaan ymmärtää vain sen sosiologistisuudesta käsin. Häntä voi ymmärtää paremmin suhteessa "suomalaisen kansakunnan" rakentamistilanteeseen ja hänen kriittisestä suhteestaan aiempiin yhteiskunnallisvaltiollisiin teorioihin - asetelmasta, joka esittäytyy myös vuoden 1922 ohjelmakirjoituksessa.

Lapsuudestaan asti Ruutu oli kulttuurikodissaan omaksunut toimintamalleja kansakunnan päätöksentekoa varten - aina Yrjö Koskista myöten (Ruutu 1954, 22). 1910-luvulla hänestä kehkeytyikin ylioppilaspoliitikko, itsenäisyysmies ja kalterijääkäri koluten myös Spalernajan vankilan. Hänen poliittisesti aloitteellinen toimintaeetoksensa oli varsin yhteiskunnallinen ja nojasi valtiotieteen erityiseen mahdollisuuteen yhteiskuntaelämän suhteiden ja kansakunnan mahdollisuuksien ymmärtämisessä (Ruuth 1913; 1919). Vielä tälle Ruudun kehityskaudelle oli ominaista vahvaa ja asiantuntevaa hallitusvaltaa legitimoivat teoreettiset ja poliittiset aloitteet. Mutta jo vuonna 1920 julkaistun "Uusi Suunta" -teoksen opit valtiososialismista osoittivat hänen siirtyneen - Ruudun omin sanoin ilmaistuna - "Rubiconin ylitse" porvarillisesta leiristä sosialistiseen (Ruuth 1920).

Valtiososialismi merkitsi monissa suhteissa hyvinkin omintakeista kansallisen sosialismin oppia - yhteisyysteoreettista maailmankuvaa, joka torjui sekä pluralismin että monismin perusajatukset. Samoin Ruudun ajatuksilla oli yhteys energeettiseen valtioteoriaan. Alun perin oppi määrittyi "valtioyhteiskunnallisuutena", missä valtio esitti kokonaisuusperiaatetta ja yhteiskunta erilaisia subjektiivisia tekijöitä. Valtioon keskitettävillä "kansallisella työllä, tahdolla ja voimalla" oli mahdollista nostaa kansalaisten elintasoa ja luoda tarvittavat sivistysresurssit. Samalla valtiososialismi yhdistyi sivistyneistön - jonkinlaisen yhteiskunnallisen keskisäädyn - erityisiin objektiivisen tiedon mahdollisuuksiin, energeettisiin tehokkuus- ja suunnitelmallisuusideaaleihin sekä kansalliseen itsenäisyyteen. Korostaessaan valtion merkitystä yhteiskunnallisessa synteesissä hän torjui pluralistisen konsensuksen lisäksi myös yhteiskunnasta nousevan vallankumouksen mahdollisuuden. Ruudun teoria ei jäänyt kuitenkaan pelkäksi etatismiksi - sivistys- 
tekijän korostaminen ja viittaukset valtion ja yhteiskunnan "mutuaaliseen" vuorovaikutukseen ja itsehallinnolliseen ulottuvuuteen sisälsivät tällaisia dialektisia aineksia. (Ruuth 1920; ks. myös Klinge 1972; Palonen 1977; Paakkunainen 1985.)

Ruudun spesifi usko sosiologis-valtiolliseen tietoon ja kansallisen sosialismin konseptio vaikuttivat monipolvisesti ja värikkäinkin muodoin ja episodein suomalaiseen yhteiskunnalliseen ja poliittiseen ajatteluun. Ruudun henkilökohtaiset toimintafoorumit vaihtelivat. 1920-luvun alun kansallista ominaislaatua jalostavasta ylioppilasmaailman "Grand old Manista" tuli monien kansallista sosialismia johtotähtenään pitävien seurojen kuulu puheenjohtaja. Näiden yhdistysten kehitys oli kuitenkin reaalipoliittisesti hyvin tempoilevaa ja toimintatunnukset jäivät abstrakteiksi. Ruutu liittyikin 1930-luvun lopussa sosialidemokraatteihin ja siirtyi sen "sotaopposition" kautta sodan jälkeen Sosialistiseen Yhtenäisyyspuolueeseen, osaksi SKDL:a. (Paakkunainen 1985.)

Omintakeisen sosialistisen aloitteellisuuden lisäksi Ruudun toiminta Yhteiskunnallisen Korkeakoulun - tulevan Tampereen yliopiston yhteiskuntatieteellisen tiedekunnan - organisoijana ja opettajana loi poliittista ja intellektuaalista etäisyyttä maan akateemiseen eliittiin. Monet aikalaiset pitivätkin Ruutua utopistina sekä hänen yhteiskunnallisen ajattelunsa että tiedepolitiikan osalta. Omat varsinaiset professuurinsa Ruutu sai vasta toisen maailmansodan jälkeen. Hän toimi kuitenkin Helsingin yliopiston valtio-opin vt. professorina vuodet 1931-38 Brotheruksen toimiessa rehtorina.

Ruudun valtiososialismilla oli paralleelit ajattelumuotonsa myös hänen valtio-opillisissa käsityksissään ja toimissaan. Pyrkimys "tieteelliseen politiikkaan" merkitsi poliittisen kulttuurin edistystä ja rationaalisesti argumentoitua politiikkaa. Toisaalta Ruudun tuotannon perusosa muodostui yleisesityksistä eikä hän juuri keskittynyt konkreettisiin ja syventäviin tieteellisiin projekteihin. (Esim. Ruutu 1932b; 1938.)

Vuosisadan alkupuolen Allgemeine Staatslehre -tradition yleisjuridisesta keskusteluasetelmasta hän poikkesi radikaalisti juuri sosiologistisen valtiokäsityksen suuntaan - juridiikka ei riittänyt valtiotarkastelussa ja useissa yhteyksissä, kuten kansainvälisen politiikan teoriassaan ja propagoidessaan valtiollisen sosiologian "edistystä", hän rakensi esityksiään juuri normatiivisen teorian kritiikin varaan. Ruutu kuitenkin ohitti Allgemeine Staatslehren melko yliolkaisesti syventymättä sen ristiriitoihin tai kehittämismahdollisuuksiin. Tällainen teoreettinen etäisyys reaalivaltion legitiimisyydestä antoi kuitenkin Ruudulle monen tyyppisiä mahdollisuuksia valtio-oppinsa kehittämisessä. Hän kuitenkin menetti osan näitä mahdollisuuksiaan sitoessaan ajatteluaan energeettiseen valtiososialismiin, yhteisyysteoreettisiin ja "objektiiviset" arvot saaviin ideaaleihin. Näiden tavoitteiden toteuttaminen heijastui reaalivaltioiden tarkasteluun. Yhteiskunnalliset erikoisedut ylittäneessä ja rationaaliset maksiimit oppineessa poliittisessa kulttuurissa oli myös yhtenäinen valtiotahto mahdollinen ja tämä kehitystie näyttäytyi Ruudulle legitiiminä. (Ruuth 1920; 1922a; 1924a; 1932a; Palonen 1980, 104-114; Paakkunainen 1985.)

Väitöskirjassaan (1922a) Ruutu eritteli yhteiskunnallisia ryhmiä ja niiden suhdetta poliittiseen kokonaisuuteen, kansakuntaa "sisäisesti energeettisenä kokonaisuutena" ja "ulkopoliittisesti energeettisenä yksikkönä". Väitöskirja pyrki hahmottamaan poliittisia subjekteja - jotka muodostuivat lähinnä ryhmätasolla. Tehtävä merkitsi Ruudulle laajemminkin valtio-opin ydinkysymystä. Väitöskirjoitus sisältää samalla monimuotoisen monistisen ja pluralistisen valtioteorian kritiikin. Monismissa - miellettäessä valtio "yhtenäiseksi valtiolliseksi kokonaisuudeksi" 
- saavutetaan yhteiskunnallisten pyrkimysten yhteisyys Ruudun tekstien mukaan "liian suoraan". Tulkinnan mukaan ryhmien väliset konfliktit sekä yhteiskunnan ja valtion välinen jännite jäivät problematisoimatta. Ruutu ei käsittänyt yhteiskunnallisia ristiriitoja myöskään yhteiskunnan ulkopuolisina häiriötekijöinä. Mutta häntä ei voi pitää konfliktiteoreetikkonakaan. Hänen konfliktinsa voidaan nimittäin mieltää eräänlaisina momentteina. Yhteiskunnallinen kehitys tarkoittaa tällöin prosessia, jossa on koko ajan mahdollista saavuttaa entistä korkeampia yhteisyysmuotoja - ja muutos tapahtuu juuri näiden momenttien yli tai niiden kautta. (Erit. Ruuth 1922a, 72-73; tulkinta yhteisyysteoriasta, ks. Palonen 1977, 310-312.)

Ruutu torjuu toisaalta pluralistisen ajatusmallin, koska se aina jossain määrin perustui ajatukseen spontaanisti muodostuneesta yhteisyydestä. Sosiaalisen harmonian rakentaminen on Ruudun kirjoituksissa mahdollista vain valtiollisen välityksen avulla. Ruudun teksteille ominainen tiukahko historiallisuus muodostui myös pluralismin ja monismin kritiikin argumentiksi. Ruudun valtioteoria ei muodostu kuitenkaan kovin selkeäksi tai toimivaksi kokonaisuudeksi. Tämä tulee esiin muun muassa hänen ajatuksissaan valtion suhteesta "kehitysvälttämättömyyksiin". Vaikka yhteiskuntaelämä merkitsikin Ruudulle historiallista prosessia, "alituista pyrkimystä”, hän korosti, että "... valtiotaidon tehtävänä on kehityksen mukanaan tuomien ristiriitojen ratkaiseminen kunakin aikakautena ja kussakin tilanteessa vallitsevien olojen edellyttämällä objektiivisella tavalla”. (Erit. Ruuth 1924a, 122-123.) Tällaisten objektiivisten ja yleisinhimillisten kehityskriteerien johtaminen ja valtion juuri poliittisesti ongelmalliset mahdollisuudet näiden arvojen artikuloijana ja läpiajajana jäävät epämääräisiksi Ruudun teoriassa. Kyse on klassisesta teoriaa määrittävien objektiivisten arvojen johtamisongelmasta, jota Ruutu ei kunnolla käy läpi.

Ruudun ajattelu- ja kirjoitustapa suosi runsaiden peruskäsitteiden ja erilaisten määritelmien käyttöä. Usein nämä jäävät keskenään ristiriitaisiksi ja teoriat eklektisiksi. Samalla hän problematisoi valtio-opillisia peruskäsitteitä monissa suhteissa aina eksegetiikasta käytännön yhteiskuntateoriaan ja tiedepoliittisiin aloitteisiin. Tällainen pyrkimys ja käsitteellinen ristiriitaisuus ei tietenkään välttämättä ole huono asia. Mutta olennaiseksi piirteeksi Ruudulla jää myös se, että tietoteoreettinen ja ontologinen arviotaso puuttuvat systemaattisesti hänen teksteistään. Hänen teoksensa hahmottuvatkin kokonaisuuksina, tietynlaisina kritiikkimuotoina, omaa kulttuuri- ja teoriataustaansa vasten. (Palonen 1980, 106-107; Paakkunainen 1985.)

Esimerkiksi energeettisen yhteiskuntateorian käsitteet jäivät epämääräisiksi. Ne kuitenkin muodostuivat elimelliseksi osaksi Ruudun kielenkäyttöä. Näin mahdollistui rationalistinen ja holistinen tarkastelutapa, joka antoi lujan pohjan kritisoida epäyhteiskunnallisia ja -historiallisia ajattelutapoja, ehkä eniten juuri positivismia ja induktivismia. Samalla rakentui yhteys staattisesta ja analyyttisesta tutkimustavasta dynaamiseen, yhteiskunnalliset suhteet ja näiden synteesin huomioon ottavaan tarkasteluun. (Ruuth 1922a; ks. myös Klinge 1972, 30-36, 44; Paakkunainen 1985.)

Lähinnä saksalaisen luonnontutkijan Wilhelm Ostwaldin energeettinen valtioteoria inspiroi Ruutua. Ostwaldin mukaan kaikki inhimillinen toiminta oli käyttöenergian lisäämistä, energian monimuotoista muuttamista. Valtio tarkoitti tällöin "inhimillisen energian tehokasta yhdistämistä yhtenäisiä tarkoituksia varten”. (Ostwald 1909.) Ruutu ei kuitenkaan jäänyt hänen oppilaakseen vaan kykenee torjumaan tämän luontoanalogiat ja -reduktionismin. Objektiivinen politiikkamuoto oli Ruudun mukaan tietoinen yhteiskunnallisten osaenergioiden kehityksestä ja riippuvuussuhteestaan yhteiskunnalliseen energeettiseen kokonaisuuteen. Kokonaisenergia ei 
merkinnyt osaenergioiden summaa vaan "kokonaisuuden yleisiin maantieteellisiin ja historiallisiin edellytyksiin perustuvaa erikoista ja yhteiskunnallista poliittista yksilöllisyyttä". Politiikan energeettinen tulkinta merkitsi siis "kansallisenergian käyttämisen ja tehokkuuden lisäämisen edellytyksenä olevien seikkojen järjestämistä ryhmien ja ajatussuuntien välisten sopimusten ja yhteistyön pohjalta".

Lisäksi politiikkakäsite saattoi viitata kansallisenergian välittömäänkin käyttämiseen. Myös valtio merkitsi "instrumenttia" - kansallisenergian käytön yhteiskunnallista orgaania. Yhteisyysteoriansa mukaisesti Ruutu korosti kansakunnan mahdollisuuksia ylöspäin suuntautuneeseen yhtenäisyyteen, mikä voitiin taata nimenomaan valtion avulla. Myös Ruudun työkonseptio ja usko tieteelliseen yhteiskuntateoriaan sai tukea energetiikasta. (Ruuth 1922a, 72-76, 85-86, 163-172; 1922b, 1924b, 331-342; Palonen 1977, 314-318.)

Spesifit energeettiset tulkinnat yhdistyivät "yhteiskunnalliseen historiantulkintaan", joka merkitsi Ruudulle "kansanvaltaisen valtioteorian perustaa". Sen ydinmerkitys oli siinä, että se mahdollisti valtion ja vallan tarkastelun painopisteen siirtämisen hallituksista yhteiskunnallisten ryhmien suuntaan. Näin Ruutu osallistui akateemisen, empiirisen ja reformistisen sosiologian tulkintaan: Lester Ward, L. T. Hobhouse sekä Henry George olivat tässä tärkeitä. Individualismin kritiikin lisäksi korostuivat yhteiskunnallis-rakenteelliset selitystasot, taloudelliset, poliittiset ja henkiset valtasuhteet sekä työkäsite. Mutta Ruutu ei jäänyt rakenne- tai sosiologiseen reduktionismiin: "parhaimmillaan" poliittinen aktiivisuus tarkoitti "spontaanisti kehittyneen yhteiskunnallisuuden" järkevää ja luovaa alistamista, sen kontrollia. Sosiologisen valtiotutkimuksen lisäksi Ruudun teorian lähteiden ja viriketaustan piiristä ei voi unohtaa Ratzenhoferin "henkilöllistymisteoriaa" eikä kiltasosialismia. (Ruuth 1920, 120-139; 1922a, 27-36; 1924b, 339-393; Palonen 1980, s105-106, 110-114; ks. myös Hobhouse 1913; Cole 1920; Ratzenhofer 1983; Ward 1916.)

Näin politiikkatiede muodostui Ruudulla "järjestelmällisestä ja objektiivisesta" yhteiskunnallisesta ja poliittisesta tiedosta - jolloin kyettiin irtautumaan "umpimähkäisestä ja sokeasta" suhteesta valtiolliseen elämään. Ruudun metodinen käsitys rakentui paljolti muiden tieteellisten traditioiden kritiikin varaan ja oli "lähinnä sosiologinen". Samalla yhteiskunnan perinpohjainen tuntemus merkitsi kaiken objektiivisuuden perustaa. (Ruuth 1922b.) Institutionalisoituneen tieteenalan määrittelyssä Ruutu ei välttämättä päässyt kovin omintakeisiin tuloksiin. 1920-luvulla hän luki valtio-opin alaan sanan "laajemmassa mielessä" myös julkisoikeuden eri alueet, kun taas "ahtaammassa" mielessä siihen sisältyivät valtioteoria, valtiosääntöoppi ja valtiotaito eli politiikka sekä valtiotieto. (Ruuth 1927.)

Oman kiinnostavan tason ja alueensa Ruudun kirjoituksissa muodostaa kansainvälisen politiikan tutkimus ja sen määrittely. Jo 1930-luvulla Ruutu kehitteli "internationalismiaan" intressiperustaisen käsitejärjestelmän perustalla. Toisen maailmansodan aikana ja sen jälkeen suurvaltapoliittinen realismi ja intressipiiritarkastelut tulivat mukaan Ruudun, maan ensimmäisen kansainvälisen politiikan professorin (1948), töihin. 1950-luvun taitteessa Ruudun kiinnostava - mutta osin epämääräiseksi jäänyt - kansainvälisen politiikan tutkimuskohde merkitsi "kansainvälisten suhteiden tutkimista kehityksen ja muuttuvaisuuden valossa sekä niistä johtuvien valta- ja voimasuhteiden järjestelyä poliittisten sopimusten ja muiden järjestelyjen puitteissa”. (Erit. Ruutu 1934; 1943; 1951.) 


\section{RAFAEL ERICH - ITSENÄISEN SUOMEN OIKEUSOPPINUT VALTIO-OPIN MÄÄRITTELIJÄNÄ}

Valtio- ja kansainvälisen oikeuden professoriksi vuonna 1910 nimetyn Rafael Erichin tieteelliset ja poliittiset yhteydet ja intellektuaalinen vaikutusvalta saivat omat vahvat muotonsa jo vuosisadan alkuvuosikymmeninä. Hänen aktiviteettejaan onkin verrattu Leo Mechelinin valtiomiestoimintaan tai Robert Hermanssonin rooliin Suomen ja Venäjän välisen yhteyden aikaisen valtiollisen oikeussuhteen selvittämisessä. Erich ei toimissaan kuitenkaan tyytynyt vallitseviin tulkintoihin. Hän ei hyväksynyt Mechelinin oppia siitä, että Suomi ja Venäjä olisivat olleet keskenään tietynlaisessa reaaliunionissa. Samoin hän arvosteli käsitelainopillisen edeltäjänsä ja "pyhän oikeusjärjestelmän" legitimointiin taipuneen Hermanssonin tieteisopillisia ajatuksia Suomen ja Venäjän keisarikunnan yhdessä muodostamasta Venäjän valtakunnasta. (Ks. erit. Erich 1912; aikalaistulkinnasta Erichin merkityksen suhteen, ks. Kaira 1940.)

Erichin mukaan tämä valtioyhteys oli luonteeltaan hyvin spesifi eikä sopinut mihinkään valmiiseen kansainvälisen oikeuden kategoriaan. Laaja-alaiseen tieteelliseen aktiivisuuteen liittyi Erichin poliittiset interventiot sortovuosien oikeustaistelussa, "Suomen kysymyksen" tunnetuksi tekemisessä ja itsenäisyysliikkeessä. Kerrotaan, että hän olisi luopunut vuonna 1917 joksikin ajaksi jopa professorin toimestaan kyetäkseen suoriutumaan itsenäisyysliikkeen velvoituksista. (Ks. Erich 1917; Kaira 1940, 180-182.)

Erichin oikeudellis-valtiollinen kompetenssi antoi hänelle tärkeän tulkitsijan roolin rakennettaessa Suomen valtiosääntöä ja oikeusjärjestelmää. Vaikka Erichille olikin historiallisesti ainutkertaista se, että Suomen itsenäistymisprosessissa kyettiin ylläpitämään aikaisemmin vieraan "vallanalaisen yhdyskunnan oikeusjärjestys ja omintakeisuus" (Erich 1939, 12-17), hän ei tukeutunut pelkkään yksinkertaiseen konservatiivisuuteen. "Valtiollisen järjestyksen kahleita katkova muutos" saattoi olla jonkin kansan sisäistäkin elämää laajemmin "siveellisesti oikeutettu": "Salus rei publicae - suprem lex', valtion onni ja elinetu on korkein laki, on periaate, joka sellaisessa käännekohdassa saattaa oikeuttaa ja oikeuttaa muodollisista velvoituksista poikkeavan menettelytavan" (Erich 1917, 5-6).

Monien aikalaisakateemisten tavoin Erich tuli mukaan välittömiin valtiollisiin tehtäviin eduskuntaan ja toimi kokoomuslaisena pääministerinä poliittis-strategisesti tärkeinä vuosina 1920-21. Hänen professuurinsa jaettiin kahtia vuonna 1921 valtio- ja kansainvälisen oikeuden kesken, ja hän halusi valita jälkimmäisen. Kansainvälisesti häntä voidaan pitää maan 1920- ja 1930-lukujen tunnetuimpana oikeusteoreetikkona. K. J. Ståhlberg vaikutti tuolloin vahvasti lähinnä kansallisen valtiosääntöoikeuden piirissä. Tieteellisten töiden lisäksi tätä Erichin roolia tukivat Kansainliittoaktiviteetit, diplomatian tehtävät sekä jäsenyys "Pysyväisessä kansainvälisessä tuomioistuimessa". On kuitenkin esitetty, että Erichin poliittinen ura ei ollut "hänen korkeista asemistaan huolimatta onnistunut" hänen "tuittupäisyydestään" johtuen. (Klami 1977b, 84-85; Kaira 1940.)

Varsinkin kansallisessa valtiosääntötulkinnassa Erichiä voidaan pitää "monarkistis-konservatiivisena" - esimerkiksi presidenttikeskeisen parlamentarismitulkinnan osalta (Jyränki 1981, 143-150). Käytännön toimissaan ja opetustyössään hänestä muodostuikin yksi keskeisimmistä juristeista, jotka rakensivat maahan ideologisesti ja työnjaollisesti vahvan legalistisen valtiollisen ajattelun perinteen. Tradition mukaan oikeusnormit muodostivat valtiollisen ja poliittisen toiminnan keskeisimmän perustan ja jatkuvuuden, joka täydentyi oikeusdogmatiikalla ja 
deduktiivisuudella. Varsinkin sortovuodet olivat muokanneet Erichin vahvaa legalismia ja sen osin tiukkaakin tulkintaa.

Samoin Erichin valtioteoreettisissa premisseissä tuntui vanhan konservatiivisuuden ja patrioottisuuden perintö, joka erottautui esimerkiksi 1930-luvun äärioikeistolaisuudesta ja -nationalismista: "Itsenäisen valtion olemassaolo on todellinen ydinkysymys meidän valtiollisessa elämässämme". Myös vanhat Allgemeine Staatslehre -tradition saksalaiset edustajat jäivät pois kansallissosialistisen Saksan oikeusjärjestelmän muokkaamisesta. 1930-luvulla Erich ei ollut valmis korvaamaan valtio-käsitettä totalitaarisemmalla kansakuntakategorialla. Hänen teoreettisen ja käytännöllisen toimintansa julkilausuttuna ideaalina olikin tietyn tasavertaisuuden ja lailla kontrolloidun yhteisyysopin sisältämä "tunteenomainen Patria" - jossa esivallan legitiimisyys olisi taattu. (Erich 1939; 1924-25.)

Kansainvälisen oikeuden pitkäaikaisena päätulkitsijana Erichin toiminta laajeni myös oikeusdogmatiikan ulkopuolelle, valtio-opillisempiin kysymyksenasetteluihin. Toisen maailmansodankin aikana hän jaksoi uskoa Montesquieun eettiseen maksiimiin kansainvälisen oikeuden perustana: "Kansojen tulee rauhan aikana tehdä toisilleen mahdollisimman paljon hyvää, sodassa mahdollisimman vähän pahaa”. Poliittisella tasolla tämä merkitsi hyvin klassista suurvaltarealismin ja intressipiirijaon kritiikkiä. Varsinkin pienten kansojen tuli toimia aktiivisesti "kaiken oikeuden yhtenäisyyden puolesta". 1940-luvulla Erich toimikin aktiivisesti niin sanotun pohjoismaisen suuntauksen puolesta ja solmi jatkuvasti kontakteja myös länsiliittoutuneisiin sodan aikana.

Voidaankin arvioida, että Erichin vuosina 1924-25 julkaisemat kotimaiset pääteokset Suomen valtio-oikeus I-II loivat puitteet maan vahvalle legalismille pitkäksi aikaa ja näin jarruttivat realistista tutkimusta ja yhteiskunnallista keskustelua esimerkiksi puhtaan parlamentaristisen teorian pohjalta. Silti ei tule unohtaa Erichin muissa tulkinnoissaan edustamaa realismia varsinkin suhteessa moniin muihin kollegoihinsa. (Vrt. Klami 1977b, 84-85.) Erichillä oli jopa inspiroiva vaikutus Ruudun sosiologisen väitöskirjan synnyssä (Ruuth 1922a, esipuhe). Lisäksi hän esiintyi vuonna 1935 perustetun Valtiotieteellisen yhdistyksen foorumilla reflektoiden juuri oikeuden käsitettä sekä valtion olemuksen että puolueettomuuspolitiikan suunnassa (Erich 1939; 1943c, 1943b, 1943c).

Erityisen kiinnostavaa Erichin tutkijakuvassa oli myös se, että hän väitellessään - samanaikaisesti sekä valtiosääntö- että kansainvälisessä oikeudessa - halusi rikkoa normatiivisuuden rajoja poliittisen prosessin ja itse spontaanisten, yhteiskunnallisten suhteiden suunnassa. Tällaista tulkintaa saattoi pitää melkoisen omintakeisuuden osoituksena - mille oli kuitenkin olemassa omat esimerkkinsä Georg Jellinekin esittämässä oikeuskäsitteistössä. Esimerkiksi myöhemmin kuuluisuuteen noussut kansainvälisen politiikan teoreetikko Hans Morgenthau onkin viitannut tähän Erichin väitöskirjaan - Über Allianzen und Allianzverhältnisse nach heutigen Völkerrecht" (1907) -ainutlaatuisena "poliittisen kansainvälisen oikeuden" problematisointina, jossa tätä tarkastelutasoa varten on kehitetty myös omat käsitteet ja metodi. (Morgenthau 1958, 229-230; Korhonen 1983, 1-39.) Toisaalta ehkä juuri kansainvälinen liittoutumisen teoria tutkimuskohteena ja Erichin tutkijaitseymmärrystä luova "Suomi-tietoisuus" auttoivat poliittisen tekijän arvon tunnustamista väitöksessä. Ei tule myöskään unohtaa laaja-alaisia opinto- ja tutkimuskontakteja jo vuosisadan ensimmäisellä vuosikymmenellä: Heidelberg, Pariisi, München, Wien, Sveitsi, Italia ja Tukholma. 
Ehkä kaikkein tarkimmaksi ja kiinnostavimmaksi Erichin valtio-oikeuksien ja valtio-opin väliseksi tulkinnaksi on jäänyt Erichin artikkeli "Muutamia huomautuksia yleisen valtio-opin asemasta tieteitten järjestelmässä ja sen suhteesta valtio-oikeuteen”. Siinä kansojen välisen oikeuden professori esittelee perusargumenttinsa valtio-opin professorin viran perustamisesta ja täyttämisestä - akateemisessa kilvassa, jossa olivat mukana filosofisesti orientoitunut historioitsija K. R. Brotherus ja filosofinen esteetikko K. S. Laurila. Lausunnonantajakollegansa ja historioitsija Georg Schaumanin kanssa hän oli yhtä mieltä edellisen - kylläkin monin tavoin ehdollisesta - pätevyydestä ja jälkimmäisen soveltumattomuudesta virkaan. (Palonen 1983, jossa on läpikäyty nimitysprosessi kokonaisuudessaan, alkuperäislähtein.)

Erichin tulkinta jää kuitenkin melko väljäksi - eikä vain tarkoituksellisesti. Erich mainitsee (1924) humanistisista aineista nimenomaan historian, valtiollisen etiikan, oikeus- ja käytännöllisen filosofian sekä sosiologian valtio-opin naapuritieteinä. Erichin valtio-opin identiteetin etsinnän epämääräisyydellä oli taustansa hänen pintapuolisessa valtio-opillisten ja Allgemeine Staatslehre -traditioiden tuntemuksessaan - huolimatta hänen tavastaan sitoa lausuntonsa saksalaisiin esikuviin, kuten Georg Jellinekiin tai ruotsalaiseen valtio-oppiin, lähinnä Rudolf Kjellenin kautta. Erityisen yksipuolinen käsitys Jellinekin ajattelusta johtunee osaltaan siitä, että hän keskittyi Jellinekin varhaistuotantoon. Tällöin kaikkinainen valtiokäsitteeseen liittyvä reflektio jää "valtio-oikeuden aputieteen asemaan". Ajatus lienee noussut Jellinekin "Allgemeine Staatslehre" -teoksesta (alkuaan ilm. 1887), jossa oikeustieteen rinnalla esiintyy spesifi akateeminen ala, "die Soziallehre des Staates". (Erich 1924; Palonen 1980, 29-80; 1983, 105-113.)

Näiden ajatusten mukaan sekä valtio-opin että valtio-oikeuden tuli sitoutua yhteisiin premisseihin, "määrättyjen valtiotieteellisten peruskäsitteiden" tasolla. Tämä merkitsi yleisemmän valtiotieteen käsittämistä filosofiseksi, hyvin lähellä oikeusfilosofiaa toimivaksi kokonaisuudeksi. Vaikka valtio-oppi sisälsikin välttämättömiä käsitteellisen tason pohdintoja, sen erityisyys valtiotieteenä voitiin jäsentää juuri "valtio-oikeudelle rinnakkaisena empiirisenä yhteiskuntatieteenä". (Palonen 1983, 106-108.)

Erich esitti Schaumanin tapaan, että politiikka oli teoreettinen ilmiö eikä jäsentynyt toiminnallisella tasolla. Sen sijaan ajatukset siitä, että politiikka tai "poliittinen tutkimus" - huolimatta näiden käsitteiden epämääräisyydestä - kuuluivat yleisen valtio-opin alaan, olivat ristiriidassa Jellinekin vahvan uuskantilaisen linjan kanssa.

Valtion olemassaolon keskeisiä pulmia lähestyivät Erichin mukaan oikeustieteen, filosofian ja humanistisesti tulkitun valtiotieteen lisäksi sosiologia eikä näiden tieteiden kohdetta voitu yksikäsitteisesti määritellä. Sen sijaan valtio-oikeus vaati tällaista täsmällistä objektia ja tämä ajatus vaikutti myös hänen tapaansa kuvata valtio-opin identiteetti - ensisijaisesti valtio-oikeuden kautta. Vaikka hänen kirjoituksensa sisälsivätkin etäisyyttä aikaisemman saksalaisen niin kutsutun Gerberin-Labandin koulukunnan valtio-oikeuden epärealistisuuteen ja antifilosofisuuteen, niin hänen ajatuksiaan voidaan lukea "Jellinekin juristissävytteisenä tulkintana" (Klami 1977b, 84-85; Palonen 1983, 107).

Kiinnostavaa on tässä yhteydessä myös se, että hänen vahvat ja substantiaaliset kokemuksensa ja tekstinsä kansainvälisen politiikan suunnalla esimerkiksi "liittoutumapolitiikan" osalta jäävät vain löyhien Kjellénin geopolitiikka- ja Montesquieu-viittausten varaan. Myöhemmin valtio-opin osana konstituoituneen "kansainvälisen politiikan" harrastajat kehittivätkin 
realistisuuttaan usein juuri Erichin tapaisten oikeuteen sitoutuneiden tarkastelujen kritiikkinä. Esimerkiksi Kansainliitto-polemiikki muodostui tällaiseksi kokoavaksi teemaksi 1920- ja 1930-luvuilla. (Erich 1924; 1907; 1926; vrt. Paakkunainen 1985.)

Erich palasi myös myöhemmin joissain suhteissa Kjellénin ajatuksia muistuttaviin valtion organismianalogioihin. Reaalihistoriallinen ja juridinen valtiokäsite eräässä mielessä kohtasivat toisensa "organismina eli elimistönä": "... juridinen henkilö ei ole syntynyt eikä valmiina 'henkilönä olemassa, niin kuin fyysillinen henkilö. Mutta sikäli kun on yleensä paikallaan puhua juridisesta henkilöstä, niin aivan ehdottomasti valtiokin esiintyy sellaisena, koska sen olemukseen kuuluu, että se on elimistö, organismi, jolle oikeusjärjestys myöntää tuon ominaisuuden eli 'statuksen"'. Tällainen organismiteoreettinen tarkastelutapa teki tavallaan turhaksi sen pohtimisen, oliko Suomen valtio tietoisesti luotu: Suomen ei tarvinnut Erichin mietteissä "ensin järjestäytyä eikä perustautua valtiona vaan valtio oli jo olemassa"; Suomen tuli ainoastaan ottaa käyttöönsä koko "suvereenille valtiolle ominainen" vallan arsenaali. (Erich 1924; 1939, 9-12.) Erichin viehtymystä jäsentää yhteiskunnallista ja poliittista kokonaisuutta juuri organismivertauksin osoitti myös hänen sodan aikana esittämänsä argumentti suurvaltarealismin kylmää "biologista lakia" vastaan: luonnossakin vallitsi "lajien monimuotoisuus ja differentoitumisen pyrkimys" - miksei siis pienilläkin kansoilla tulisi olla suurten valtioiden keskellä olemassaolon oikeus. (Erich 1943a ja 1945.)

Kirjoitus on julkaistu alun perin Valtiotieteellisen yhdistyksen kotisivuilla osana valtio-opin satavuotisjuhlavuotta käsittelevää kirjoitussarjaa. Se pohjautuu teokseen Kari Paakkunainen (toim. 1986), Valtio-oppi tieteenä. Puheenvuoroja suomalaisen valtio-opin muotoutumisesta. Helsingin yliopiston yleisen valtio-opin laitoksen tutkimuksia. Opetusmonisteet. Sarja B 19.

\section{LÄHTEET}

Ahtiainen, Pekka. 1982. Historiallisen yhdistyksen ensimmäinen neljännesvuosisata. Historian pro gradu. Helsingin yliopisto.

Anckar, Dag. 1976. Samhälle, rätt och politik. Statsvetenskapliga fakultetet vid Åbo Akademi. Forskninglärarestudentliv. Åbo.

Brotherus, K. R. 1903. Muutama sana individualistisesta ja kollektivisesta historiankirjoituksesta. HAIK.

Brotherus, K. R. 1905. Immanuel Kants Philosophie der Geschichte. Helsinki.

Brotherus, K. R. 1924a. Valtio-opin suhde muihin tieteisiin. HAIK.

Brotherus, K. R. 1924b. Valtiotieteet. Valtiotieteiden käsikirja IV. Helsinki.

Brotherus, K.R. 1924c. Valtiotaito. Valtiotieteiden käsikirja IV. Helsinki.

Brotherus, K.R. 1927. Muutamia piirteitä n.s. vapausaatteiden historiasta. HAIK.

Brotherus, K.R. 1940a. Vapaus, tasa-arvoisuus, veljeys. Valvoja-Aika 1940.

Brotherus, K. R. 1940b. Kysymys tasavallan presidentin hajoitusvallan tehostamisesta Ranskassa. Lakimies.

Brotherus, K. R. 1940c. Metafyysillisiä piirteitä historiallisessa ja poliittisessa ajattelussa. HAIK.

Brotherus, K. R. 1944. Muutamia havaintoja puolueoloista eduskunnassa. Valtiotieteellisen yhdistyksen vuosikirja 1944. 
Brotherus, K. R. 1946. Reunamuistutuksia keskusteluun demokratiasta. Valtiotieteellisen yhdistyksen vuosikirja 1945-46.

Brotherus, K. R. 1947. J. J. Rousseau demokratian filosofina. Valtiotieteellisen yhdistyksen vuosikirja 1947.

Cole, G. H. D. 1920. Social Theory. Lontoo.

Erich, Rafael. 1907. Über Allianzen und Allianzverhältnisse nach heutigen Völkerrecht. Helsingfors.

Erich, Rafael. 1912. Das Staatsrecht des GrossfUrstentums Finnland. Helsingfors.

Erich, Rafael. 1917. Valtioelämän murroskaudelta. Helsinki.

Erich, Rafael. 1924. Muutamia huomautuksia yleisen valtioopin asemasta tieteitten järjestelmässä ja sen suhteista valtio-oikeuteen. Lakimies.

Erich, Rafael. 1924-25. Suomen valtio-oikeus I-II. Helsinki.

Erich, Rafael. 1926. Kansainliiton oikeusjärjestys. Helsinki.

Erich, Rafael. 1939. Valtion olemus ja käsite tutkimuksen kohteena ja kansojen elämässä. Lakimies. (Valtiotieteellisessä yhdistyksessä pidetty esitelmä.)

Erich, Rafael. 1943a. Oikeusjärjestyksen yhtenäisyys ja pienet kansat. Valtiotieteellisen yhdistyksen vuosikirja 1942-43. (Yhdistysesitelmä)

Erich, Rafael. 1943b. Nordens sak. Finsk Tidskrift.

Erich, Rafael. 1943c. Morgondagens heroism? Finsk Tidskrift.

Erich, Rafael. 1945. Sodan ja rauhan vaiheilla. Valvoja.

Hobhouse, L. Th. 1913. Social Evolution and Political Theory. New York.

Jellinek, Georg. 1920. Allgemeine Staatslehre. Berlin.

Jyränki, Antero. 1981. Presidentti. Tutkimus valtionpäämiehen asemasta Suomessa v. 1919-1976. Juva.

Kaira, Kaarlo. 1940. R. Erich 60-vuotias. Lakimies.

Klami, Hannu Tapani. 1977a. Oikeustaistelijat. Suomen oikeustiede Venäjän vallan aikana. Juva.

Klami, Hannu Tapani. 1977b. Itsenäisen Suomen juridisia vaiheita. Kokoelmassa Oikeushistoriallisia tutkielmia I. Turun yliopiston yksityisoikeuden laitoksen julkaisuja A:5; 1977.

Klinge, Matti. 1972. Vihan veljistä valtiososialismiin. Yhteiskunnallisia ja valtiollisia näkemyksiä 1910- ja 1920-luvuilla. Helsinki.

Korhonen, Pekka. 1983. Hans Morgenthau - intellektuaalinen historia. Jälkisanat Kari Palonen. Jyväskylän yliopiston valtio-opin laitoksen julkaisuja No 46/1983.

Laurila, K. S. 1923. Onko yleinen valtio-oppi deskriptiivinen vai normatiivinen tiede? Valvoja-Aika.

Mechelin, Leo. 1912. Politiken säsom vetenskap. översigt af Finska Vetenskaps-Societens förhandlingar. LIV; 19111912. Afd.C; No 6.

Morgenthau, Hans J. 1958. Dilemmas in Politics. Chicago: University of Chicago Press.

Paakkunainen, Kari. 1985. Demokratia, tiede, kansanvalistus. Helsinki.

Palonen, Kari. 1977. Sivistyneistösosialismi. Yrjö Ruudun poliittisen teorian tulkintaa. Politiikka.

Palonen, Kari. 1980. Politiikan ja valtion käsitteiden kriiseistä suomalaisen valtio-opin historiassa. Tieteenalan perusteiden ja itseymmärryksen muuntumisen tulkintaa erityisesti suhteessa Allgemeine Staatslehre -traditioon. Jyväskylän yliopiston valtio-opin laitoksen julkaisuja No 39/1980.

Palonen, Kari. 1983. Yleisen valtio-opin perustaminen Helsingin yliopistoon. Teoksessa Jaakko Nousiainen ja Dag Anckar (toim.), Valtio ja yhteiskunta. Juva.

Ratzenhofer, Gustav. 1893. Wesen und Zweck der Politik. Als Theil der Soziologi und Grundlage der Staatswissenschaften. Bd. 1-3. Leipzig. 
Rehtorin puheet lukuvuoden avajaisissa vuosina 1923-37. Helsinki 1937.

Ruuth, Yrjö Oskar [vuoden 1927 jälkeen Ruutu]. 1913. Luettelo Suomessa ilmestyneestä yhteiskuntapoliittisesta kirjallisuudesta 1. päivään heinäkuuta 1912. Helsinki.

Ruuth, Yrjö Oskar. 1919. Valtiotieteellisistä opinnoista Suomessa. Yhteiskuntatieteellisiä kirjoituksia 16. Esitelmä Kansantaloudellisen yhdistyksen kokouksessa helmikuun 24. päivänä 1919. Helsinki.

Ruuth, Yrjö Oskar. 1920. Uusi Suunta. Suomalaisen yhteiskuntaohjelman ääriviivoja. Jyväskylä.

Ruuth, Yrjö Oskar. 1922a. Kansakunta. Poliittinen tutkimus. Helsinki.

Ruuth, Yrjö Oskar. 1922b. Poliittinen tiede ja sen metodi. HAIK 1922.

Ruuth, Yrjö Oskar. 1924a. Kehitys ja edistys valtiollisina kysymyksinä. Vertaileva esitys edistysteorioiden suhteesta valtiotaitoon ja valtiolliseen toimintaan. Helsinki.

Ruuth, Yrjö Oskar. 1924b. Valtio II. Valtio-opilliset teoriat. Valtiotieteiden käsikirja IV. Helsinki.

Ruuth, Yrjö Oskar. 1927. Lyhyt yleisen valtio-opin kurssi Työväen Akatemiassa. Helsinki.

Ruutu, Yrjö Oskar. 1932a. Ajan Vaatimus. Helsinki.

Ruutu, Yrjö Oskar. 1932b. Valtiotiedon opas. Sivistys ja tiede LXXXIV. Porvoo.

Ruutu, Yrjö Oskar. 1934. Nykyajan kansainvälinen politiikka. Jyväskylä.

Ruutu, Yrjö Oskar. 1938. Johdatus valtiosääntöoppiin. Yhteiskunnallisen Korkeakoulun julkaisuja I. Porvoo.

Ruutu, Yrjö Oskar. 1943. Kansainvälinen politiikka tieteellisen tutkimuksen kohteena. Valtiotieteellisen yhdistyksen vuosikirja 1942-43.

Ruutu, Yrjö Oskar. 1951. Kansainvälisen politiikan peruskysymykset. Julkaisematon opetusmoniste, Yhteiskunnallinen korkeakoulu, Helsinki. (Ruudun kokoelma, Valtionarkisto.)

Ruutu, Yrjö Oskar. 1954. Muistopuhe prof. J.W. Ruuthin syntymän 100-vuotispäivänä pidetyssä juhlatilaisuudessa. Hyvinkää.

Ward, L. T. 1916. The Psychic Factors of Civilization. Guing \& Somp.

\section{KIRJOITTAJATIEDOT}

\section{KARI PAAKKUNAINEN}

VTL, nuorten poliittisen kulttuurin tutkija Nuorisotutkimusverkostossa

HY:n yliopisto-opettaja (eläkkeellä) 